\title{
PRESENCIA TOJOLABAL EN LAS FIESTAS PATRONALES DE COMITÁN, CHIAPAS, MÉXICO
}

\author{
The presence of the tojolobales in the patron saints \\ festivals of Comitán, Chiapas, Mexico
}

Alexander Ruíz Beltrán ${ }^{1}$ Fernando Limón Aguirre ${ }^{2}$

Fecha de recepción: 18 abril de 2017

Fecha de aceptación: 07 junio de 2017

1- Nombre: Alexander Ruíz Beltrán. Nacionalidad: Cubana. Grado: Maestro. Especialización: Historia de la formación nacional y el pensamiento cubano. Adscripción: El Colegio de la Frontera Sur. Correo electrónico: alexruizbel@hotmail.com

2- Nombre: Fernando Limón Aguirre. Nacionalidad: Mexicana. Grado: Doctor. Especialización: Sociología. Adscripción: El Colegio de la Frontera Sur.. Correo electrónico: flimon@ecosur.mx 


\section{Resumen}

Este artículo aborda la participación del pueblo maya tojolabal en fiestas patronales y romerías de la ciudad de Comitán, Chiapas y poblados circunvecinos. Su objetivo es conocer las aportaciones socio-históricas y culturales de esta población a la ciudad y la región. La observación participante incluyendo conversaciones, entrevistas espontáneas y dirigidas a actores claves, visitas a hogares y acompañamiento en las caminadas, como parte de un proyecto memorístico y etnográfico, permitieron identificar la variedad de símbolos implicados. La realización de estas actividades pone de manifiesto el deseo de una construcción constante del sentido comunal, de sacralidad, de relación con la naturaleza y de la memoria como elementos clave en el modo de vida de los tojolabales $y$ de su presencia en el espacio urbano.

Palabras clave: ciudad Comitán, conocimientos culturales, indígena maya tojolabal, romerías, San Caralampio.

\section{Abstract}

This article centres on the participation of the Mayan-tojolabal population in the patron saints festivals and pilgrimages of the city of Comitán, Chiapas, and neighboring settlements. The objective is to gain knowledge about the historical and cultural contributions of this population to the city and the region. Participant observation, including conversations, spontaneous and directed interviews with key actors, visits to homes and accompaniment in various peregrinations, formed part of an ethnographic memory project, and permitted the identification of a variety of implied symbols. The realization of these religious activities is indicative of a desire for the constant construction of a communal sense of sacrality, of relations with nature and with memory as key elements in the way of life of the tojolabales, and of their presence in the urban space.

Keywords: Comitán city, cultural knowledge, indigenous maya tojolobal, pilgrimages,San Caralampio. 


\section{Introducción}

$\mathrm{E}$

1 presente estudio de la presencia tojolabal en las fiestas patronales en la ciudad de Comitán de Domínguez, Chiapas, México y en poblados circunvecinos tiene como base un trabajo de tipo memorístico y etnográfico realizado en el marco de una investigación sobre la memoria del origen multicultural de esta ciudad, que ha venido realizándose de finales del año 2014 hasta principios de $2017^{3}$. Mediante observación participante con conversaciones, entrevistas espontáneas y dirigidas a actores claves, visitas a algunos hogares y acompañamiento en las caminadas, se pudo constatar que este pueblo indígena tiene un calendario anual de visitaciones a fiestas patronales de la región teniendo como punto de partida sitios de la ciudad y que, en unión con pobladores comitecos, se trasladan en procesiones y romerías hasta la sede de los santos patronos.

La ciudad de Comitán de Domínguez, ubicada en el centro-este del estado de Chiapas, cercana a la frontera con Guatemala, ha sido reconocida como Pueblo Mágico por su riqueza cultural, histórica y de tradiciones. La presencia de varios pueblos originarios, conjuntamente con sus tradiciones y festividades, son patrimonios intangibles que se articulan con sitios concretos que ponen en evidencia el dinamismo cultural que va más allá de las formas folklorizadas con que se suele atraer visitantes y recursos y, al mismo tiempo, ponen en cuestión las formas oficiales y oficiosas de comprender la historia, las dinámicas culturales y las formas de simbolizar la vida y sus dinámicas por parte de los pueblos.

Las fiestas patronales, estudiadas entre muchos otros por Briones (1991), Fernández (1995), Grimson (1997), Inestrosa (1994), tienen como rasgo característico que son espacios de confluencia entre lo religioso y lo profano. En este tipo de fiestas celebradas en Comitán y en lugares circunvecinos se pone de manifiesto, conjuntamente con la memoria colectiva de los pueblos allí presentes, la vertebradora presencia indígena en esta ciudad a la que durante muchos años a través de cronistas urbanos se intentó atribuírsele el carácter de ser una ciudad eminentemente mestiza.

Historiadores, cronistas, antropólogos, profesores, escritores, académicos, conferencistas, etnólogos y lingüistas, quienes reconocen la presencia ancestral de pueblos indígenas, tales como: Argüello (1981), Basauri (1931), Becerra (1932), Fábregas (2012), Gómez y Ruz (1992), Lenkersdorf (1979; 1996), Lenkersdorf (1986), Pulido (2006; 2010), Rodas (1968), Ruz (1981; 1982), entre otros autores que componen la historiografía local se han concentrado en el estudio de las prácticas culturales y costumbres de los tojolabales de esta zona de Comitán; sin embargo, cuando abordan las fiestas regionales lo hacen de una forma superficial sin abundar en las experiencias, expresiones, vivencias y sentido de sus participantes.

$\mathrm{Al}$ describir algunas fiestas patronales consideradas como las más destacadas, omiten ver de conjunto los elementos simbólicos, así como las pautas y ritmos del calendario festivo regional donde se constatan hilos articuladores de sentido. Los diversos autores reconocen la importancia de la Fiesta de San Caralampio, no obstante ninguno aborda los porqués queda erigida la plaza de La Pila, del barrio del mismo nombre, como centro de estas participaciones indígenas y no reparan en la variedad de símbolos y significados presentes en estas celebraciones rituales. Con el presente texto deseamos dejar constancia de

3- Agradecemos la Beca de Conacyt No. 507129/307790 al primer autor.

Alexander Ruíz Beltrán / Fernando Limón Aguirre 
las aportaciones tanto socio-históricas como culturales que hacen los indígenas mayas tojolabales a esta ciudad y a sus regiones vecinas con sus participaciones en dichos eventos culturales.

Pérez y Vargas (2009: 90) plantean que: "la construcción de la identidad cultural en los grupos étnicos es un proceso dinámico que implica una continua recreación, y es en las actividades rituales, como las fiestas, donde se fortalece la memoria colectiva y, por ende, el sentido de pertenencia”. Pero, en Comitán dicha "continua recreación" tojolabal no queda circunscrita a sus integrantes sino que tiene un alcance mayor con influencia generalizada y creciente en la ciudad. Es la propia creatividad de los pueblos originarios que dejan una impronta en un colectivo social mayor, contribuyendo también a la memoria y a la identidad del colectivo.

Debe advertirse que esta identidad cultural, notoriamente específica de los pueblos indígenas, en este caso la de los tojolabales, se construye en un dinamismo que al mismo tiempo tiene que hacer frente a las tendencias contextuales hegemónicas, modernizantes, y defenderse de sus pretensiones, cuando no de una homogeneización, sí de la imposición de una identidad a modo que es contributiva de la lógica hegemónica de los grupos de poder.

A este respecto y teniendo en cuenta la relación existente entre la identidad cultural y creatividad de los pueblos, iniciemos con una reflexión sobre el tema de "la cultura", pero no en abstracto, sino concretamente las llamadas "culturas indígenas".

\section{La cultura de los pueblos indígenas}

El criterio de Pérez y Vargas (2009), citado arriba, nos induce a tratar aquí el tema de la "cultura" de los pueblos y en particular aquella de los pueblos indígenas; que, además de versar sobre un elemento importante en el debate de las ciencias sociales actuales, lo estamos problematizando desde el antagonismo que se reproduce en el imaginario social -al menos regional- en cuanto a la asociación e identificación de lo urbano con lo no indígena o mestizo y, por tanto, a lo indígena con lo rural. Se trata de una interpelación que se hace desde la negatividad y la no-identidad (Adorno, 1990) a la asignación e imposición de identidades convenientes a las hegemonías, igual que a la invisibilización y a la exclusión padecidas por los pueblos bajo las lógicas de la colonialidad (Quijano, 1993).

Atendiendo a lo antes dicho, pensemos en el término de cultura, primeramente en el entendido de que "la vida humana sólo es posible como cultura", como lo expresa San Martín (1999: 183) y, sobre esta base, le comprendamos en el diálogo que nos ofrecen la perspectiva antropológica, como creatividad (Fábregas, 2012), pero también desde una aproximación sociológica como modo de vida y negatividad, ante lógicas sistémicas totalizantes (Limón, 2010). Fábregas (2012: 12) plantea que: "la cultura es el resultado de la capacidad humana para crear un mundo propio. Así pues, todo producto humano es cultural". Entonces la cultura, "cultivo de lo inmediato y espontáneo de la vida" (San Martín, 1999: 134), es ante todo modo de vivir y creación.

Aunque Fábregas expone una distancia entre la capacidad y la creación de tal mundo, dicho intersticio es precisamente ocupado por la cultura, que no es otra cosa sino la resultante de dicha capacidad, semejante por tanto al mundo propio. Pero a nosotros nos interesa enfáticamente la dimensión colectiva, concretamente la noción de pueblo, hacedor de mundos de vida, en espacios determinados y vividos 
como territorios; éstos a su vez son reproducidos a partir de relaciones con sentido, lo que nos articula a la noción de conocimientos culturales que se verá más adelante.

Pero, profundizando primeramente en lo propuesto por Fábregas (2012: 12), él plantea que: "una parte clave de la cultura es la capacidad humana de crear símbolos, dotarlos de significado y transmitirlos socialmente". Esto nos lleva a asumir que el pueblo tojolabal ha creado sus símbolos, dotándolos de significado y que los sigue transmitiendo, de donde se desprende una pregunta: ¿a quiénes y cómo? Al realizar sus prácticas culturales articuladas como formas celebrativas, públicas y populares en Comitán, lo hace ya no sólo con dirección a quienes se auto-adscriben de su pueblo que, recibiendo tal simbología, alimentan la construcción de su propio mundo de vida, sino que también lo hace a la gente que habitando en la ciudad de Comitán, y deslindándose de auto-adscribirse tojolabales, se involucra en tales festividades.

Como pueblo indígena, los tojolabales enfrentan esa histórica tensión entre recuerdo y olvido (Aróstegui, 2004), relacionada concretamente con la preservación de sus raíces y valores culturales y espirituales pero, a su vez, atravesada por la historia de colonización. Pero vayamos hilvanando nuestro argumento con base en las expresiones que pudimos registrar en nuestro trabajo y, de esta manera, dar mayor peso etnográfico a nuestra exposición.

Ramón Gómez Morales es una persona de 72 años, maya tojolabal nacido en la colonia Bajucú, del municipio de Las Margaritas, desde niño se trasladó con su familia, sus padres y abuelos, a vivir en Comitán. Junto a su esposa Bertha Morales participa tocando tambores, carrizos o pitos y caracol en las fiestas patronales y peregrinaciones anuales que parten desde esta ciudad. Actualmente se dedica a fabricar tambores en su propia casa. Él se constituyó para nosotros en un informante clave y de calidad. Debido a sus ricas y profundas aportaciones y a la elocuencia de las mismas, acudimos a sus expresiones en reiteradas ocasiones, pues ilustran de forma sintética una forma de apreciar y vivir la temática de nuestro estudio. Él nos habla de la muerte que significa la "ruptura" de las culturas: "Seguir la cultura es vida, si se rompe es muerte. Es muy doloroso desaparecer culturas. En la radio hablan de defender la cultura. Y, ¿de qué cultura hablan? Si ésa va desde las raíces, sus padres, la lengua. Me da risa que se habla políticamente de rescatar culturas. ¿Cuál cultura? Las culturas se están acabando por las ideologías y las sectas religiosas" (25-04-2016).

Con preclara idea expresa imágenes dialécticas de la cultura y la encrucijada en que se encuentra, entendiéndola en concordancia con San Martín (1999) como vida. En el contexto en que se ubica, no debe extrañar el señalamiento a las "sectas religiosas", pues éstas desde décadas (con creciente número de adeptos) se han pronunciado reticentes a las expresiones culturales de los pueblos originarios en esta región, oponiéndose directamente a su realización. Pero el señalamiento a las ideologías es un correlato a las políticas a que se refiere, pues son el sustento de las mismas. A pesar de que en sus relaciones de coexistencia los tojolabales han logrado refrendarse como tales, recreando su propio mundo con el que hoy definen su particular identidad, esto lo hacen en medio de políticas y disposiciones discriminatorias y la imposición de identidades convenientes al sistema hegemónico.

Manteniéndonos aún en la cultura como creación, siempre de frente a su destrucción o muerte, con franca memoria histórico-política y hasta religiosa, el mismo Ramón se expresa: "Yo quiero hacer florecer

4- Dígase aquí las iglesias Presbiterianas, Adventistas del Séptimo Día, Testigos de Jehová, Bautistas, Nazarenos, Pentecostés, entre más de tipo evangélico y pentecostal. 
la cultura como lo hacían mis antepasados. El pueblo político quiere aplastar a los indios. La exclusión política. El indio no tiene la palabra, no tiene derecho, no tiene lugar. Ésta es la historia de la circuncisión: si no estás circuncidado estás fuera, no eres parte de nosotros" (25-04-2016).

La dificultad por la recreación cultural indígena es un fuerte reclamo a la discriminación y la exclusión que sufren como pueblos originarios. En este mismo sentido Escalante (2014) $)^{5}$, activista contra la discriminación étnica y racial', remarca que en las "ciudades es donde los indígenas reciben más discriminación porque se considera que éstas no fueron hechas para ellos, que no pertenecen a ese lugar" ${ }^{7}$. No obstante, la presencia indígena hoy en las urbes crece y con ello se disminuye la presión a asimilarse y a dejar su particular modo de vivir.

Sin embargo, esta aspiración por un trato respetuoso no es fácil, y para la gente indígena que vive en las ciudades y que busca recrear su propio sentido, sus propios mundos y culturas, las urbes pueden representar pesadillas donde recurrentemente pasan a ser víctimas de la psicosis, la maleabilidad y el totalitarismo (Harvey, 2008). Los contextos de urbanización generalmente son homogeneizantes, en donde la dimensión cultural de la existencia se busca que sea subsidiaria de las lógicas económicas que están soportadas por ideologías modernistas y mercadológicas; esto trae consigo afectaciones culturales en los ámbitos locales sobre los pueblos, entre ellos los indígenas.

De nueva cuenta, la elocuencia de Ramón lo expone con claridad y dolor:

La globalización ha venido a exterminar culturas. Los gobiernos vienen eliminando culturas. Las políticas han contribuido a que desaparezcan las culturas y sus tradiciones. Las reformas que ha sufrido México han acabado con la historia de Comitán y sobre todo con Balún Canán. Esto ha venido causando muerte. Hay muerte de las culturas originarias y falta de respeto. Al borrar las culturas y tradiciones se está matando. (2504-2016)

Ahora nuestro informante ya no se queda hablando de muerte, como si fuese natural, sino de matar a las culturas originarias y sus tradiciones, es el asesinato a los pueblos con cultura y tradiciones propias. $\mathrm{Y}$ es precisamente en este marco, de condiciones reales de existencia, donde es conveniente transitar a la noción de conocimientos culturales (Limón, 2010), pues remiten al modo de vida de los pueblos (sustentado en sus conocimientos), como resistencia y dignidad; son aquellos conocimientos que proyectan la vida de los pueblos, de sus mundos de vida, en el futuro como resistencia ante formas enajenantes y como dignidad.

A los conocimientos culturales los entendemos "como el referente por el cual vivimos nuestra vida

5- Autor del libro titulado "Derechos de los pueblos indígenas y discriminación étnica o racial", Entrevista a: Yuri Escalante Betancourt, Discriminación Indígena en México el 24 de agosto de 2014. Serie Voz y pensamiento de los indígenas en las ciudades y en los medios alternativos. Disponible en http://indigenasdf.org.mx

6- Según informes de la Encuesta sobre Discriminación en la Ciudad de México 2013, realizada a la población de dicha ciudad por el Consejo para Prevenir y Eliminar la Discriminación (COPRED 2013): "En México hay aproximadamente 16 millones de personas indígenas y 438 mil en la Ciudad de México, las personas indígenas son el grupo mayormente discriminado. Éstas consideran que el principal problema que tienen es la discriminación antes que la pobreza".

7- En este sentido, el Consejo Nacional para Prevenir la Discriminación (CONAPRED) en el año 2009 publicó un documento con la proclama de que se respeten los derechos de los indígenas en las ciudades. 
comunitariamente de un modo particular y característico [...] el modo como vivimos nuestra vida en comunidad" (Limón, 2010: 20). En este sentido, las prácticas socioculturales de un grupo social dado en la medida en que tienen contenido y refuerzan o confieren sentido de existencia, propio y característico, evidenciando un modo de existir característico como colectivo, son expresiones de dichos conocimientos, que son los que hacen frente a las imposiciones de creaciones culturales hegemónicas; pues, remarcando: "El conocimiento cultural, como categoría, debe ser útil contra la alienación y contra la superficialidad en la imagen del mundo y de la vida (contenida implícitamente en el modelo hegemónico y dominante) que se asienta entre los pueblos y sus colectividades, particularmente adversas a los pueblos indígenas y a sus memorias" (Limón, 2010: 29). Así que podemos remarcar la idea de que tales conocimientos, al tener un carácter cultural y precisamente por no estar vacíos de contenido, son los que articulan argumentativamente los aspectos que pautan la vida, concretamente el modo de vivir en comunidad (esto es, otorgando todos los símbolos y significados que se transmiten y que refuerzan el sentido comunitario).

Habiendo remarcado esta dimensión, podemos comprender lo que nuestro interlocutor, el mismo Ramón Gómez, afirma: "De la cultura que estamos hablando, mire usted, significa mucho, es vivencia, vida. Seguir la cultura es vida" (25-04-2016). Y fue entonces cuando se expresó en el sentido de que, "si se rompe es muerte". De tal manera que vemos que la dimensión cultural de la existencia se traduce en vivencias diarias, en la experiencia común, en la vida, en lo real y lo espontáneo que es evocado por el pueblo para darse sentido de existencia y para reconstruir su propio mundo de vida. Es, en este sentido, que hablamos de la capacidad humana de recreación de mundos de existencia y de sentido, pues de lo contrario: una cultura impuesta es y será sinónimo de la muerte asestada sobre un pueblo.

Habiendo dejado estas bases de comprensión establecidas, abordemos ahora cómo este pueblo ha ganado en presencia en el escenario de la ciudad Comitán.

\section{El pueblo tojolabal en la ciudad de Comitán de Domínguez}

Comitán debe ser entendida como una ciudad multicultural de origen indígena. Comitán es la castellanización de Comitlán, nombre asignado en nahuatl a la localidad cuyo nombre original de su pueblo fundador maya ha sido normalmente asumido como Balún Canán ${ }^{8}$. Esta ciudad es la cabecera del municipio Comitán de Domínguez. Según el último censo del Instituto Nacional de Estadística y Geografía (INEGI, 2010) alcanzaba los 97 mil 537 habitantes (de 141 mil 013 en todo el municipio); siendo los hablantes de lenguas indígenas un total de 3 mil 730 personas (de un total de 5,569 en todo el municipio ${ }^{9}$ ).

En el caso del pueblo tojolabal el origen de su presencia en este escenario comiteco es algo controversial. "Tojolabal deriva del nombre de su idioma, llamado tojol abal, [que significa] idioma verdadero. abal, corresponde a lengua, idioma, y tojol a verdadero" (Lenkersdorf, 1996: 22).

8- Nos encontramos realizando investigaciones que nos conducen a confirmar que el nombre original es B’alunh K'ana, correspondiente a una fecha del calendario maya-chuj.

9- Entre ellos 2,545 hablantes del tojolabal y 1,872 del tseltal. Las fuentes oficiales se basan en las respuestas de las personas pero, muchas veces, y esto es lo que plantean algunos líderes de comunidades indígenas, la gente no dice que habla una lengua indígena por miedo, por estigma, por exclusión y marginación, con lo que el número puede ser mayor al que se registra. Datos extraídos y actualizados del XIII Censo General de Población y Vivienda del año 2010 del (INEGI). México. 
La historia oficial gravita entre ubicarles como uno de los pueblos indígenas originarios fundadores del primer asentamiento maya de esta zona de Comitán o señalarlo directamente como el pueblo fundador. Pulido (2006: 2-3), historiadora de Comitán, en su texto: "Comitán en la Historia. Breve Historia Documentada de Comitán de Domínguez, Chiapas", escribe:

Se cree que fueron los Kokom (nombre de una de las castas toltecas que gobernaron el imperio maya de Yucatán) los primeros pobladores de este lugar. Antigua como el resto de aquellas fundaciones Balún Canán fue una ciudad populosa y fértil, sus pobladores descendientes de los maya-quiché y de una rama de los tzeltales o quelenes, se extendieron por toda la comarca e intensificaron el comercio y el intercambio cultural con los demás pueblos del centro de Mesoamérica. Por otra parte, se ha demostrado por estudios antropológicos que además de los Kokom habitaron la zona de Comitán tzeltales y tojolabales, siendo este último grupo al que encontraron los conquistadores españoles y posteriormente se replegaron a lo que hoy es el municipio de Las Margaritas.

Argüello (1981: 9) cita a Rubén Alfonso Mandujano, quien afirma:

La raza que habitó la primitiva población de Chonab o Balún Canán era la de los TOJOLABALES o CHANEABALES, descendientes de los antiguos quichés y una de las ramas de los tzeltales o de los quelenes que por lo pronto recibió el influjo de los inmigrantes de otras razas similares (tzotziles, votánides, mayas, etc.) y más tarde el de los ulmeca-tolteca-nahoas, y que constituyó un cacicazgo independiente. Su lengua, el TOJOLABAL, del grupo tzeltal... la define Flavio Paniagua como "una mezcla de tzotzil, zendal, maya y trokek" y se la llama también CHANEABAL, que se dice significa "CUATRO LENGUAS". Los tojolabales se extendieron por toda la zona comarcana de Comitán y fundaron muchos otros pueblos, los cuales tomaron mucho auge y se crearon otros más a la llegada de los toltecas en el siglo XI.

El autor llega a hablar incluso de muchos otros pueblos, pero sin ofrecer nombre alguno. Revisando la literatura y los documentos de archivos históricos, los datos apuntan en otro sentido. Ruz (1981: 39), quien en su momento hiciera la revisión archivística más exhaustiva, expresa: "El chañabal o tojolabal aparece en el panorama lingüístico del área hasta finales del siglo XVII". Y fundamenta esto: "El documento más temprano localizado hasta ahora donde se menciona a la lengua chanabal, es el libro donde se asientan las licencias otorgadas a confesores y predicadores, previamente examinados en las lenguas habladas por sus feligreses" (Ruz, 1981: 36) ${ }^{10}$.

Un aspecto que sí alcanza cierto consenso es ubicar los orígenes del grupo tojolabal en los altos Cuchumatanes en Guatemala, en la región chuj. El mismo Ruz (1982: 46), dice que se "apunta una dis-

10- El documento fue registrado para el año 1686 específicamente por eso que Ruz (1981: 43) concluye su hipótesis diciendo que: "El tojolabal o chañabal, como lengua particular, es mencionada en el Obispado de Chiapas hasta 1686, época en que se reporta aún la existencia del coxoh y el cabil, con las cuales se ha pretendido identificarla. 
persión desde los Cuchumatanes hacia Chiapas en la que participaron tzeltales, tzotziles y tojolabales". Aréchiga desde la antropología física y citado por el mismo autor encuentra que "la similitud física del grupo tojolabal con la rama chuj-kanjobal es mayor que la que presenta con el grupo tzeltal-tzotzil”.

La memoria histórica de los chuj respalda esta hipótesis, así como las romerías que hacen los tojolabales a las tierras altas de los chuj, a San Mateo Ixtatán, en el sentido de que el grupo tojolabal de allá provino. No se conoce bien a bien cuándo, pero Ruz (1982: 47) apunta: "Quizá la explicación más plausible es que el grupo haya permanecido, en los inicios de la Colonia, en las zonas selváticas o montañosas cercanas. Transcurrido el tiempo, el grupo se viera finalmente obligado, por el avance conquistador, el celo misionero o el empuje de otros grupos cercanos, a descender paulatinamente al somontano". En este entendimiento, los tojolabales no pueden ser considerados los fundadores de Comitán.

A todo esto hay que añadir lo que Carlos Lenkersdorf (1979: 5) asevera y que ha sido sumamente confirmado y reiterado: "La memoria de los tojolabales hoy en día comienza con el baldío sin saber cuándo el baldío se inició". El baldío (Gómez y Ruz, 1992) es la forma de nombrar al período histórico en que fueron mozos en haciendas. Así que sus memorias más atávicas se adhieren tan solo a las fincas (¿cien, doscientos años?, ¿cuántos?). Los tojolabales no elaboran argumentos que expresen recuerdos de su pasado prehispánico ni de apego territorial alguno de dicha época y son un pueblo que no tiene centro cultural prehispánico propio y reconocido que favorezca su congregación y la memoria.

La gente de este pueblo, independientemente de lo anterior, tiene hoy en día una presencia indiscutible en el escenario comiteco, tanto como pobladores del propio espacio urbano, como de quienes provienen de localidades de la contigua y vasta región que habitan para mercar o atender asuntos. Su presencia es particularmente notoria e imprescindible en algunas de las fiestas de los santos patronos de los barrios y allende el espacio urbano. En el siguiente apartado abundaremos en qué dicen los tojolabales respecto al por qué erigen a la ciudad de Comitán como el punto de partida para las salidas a fiestas patronales y romerías.

\section{La Pila: alma tojolabal para las romerías}

Si hay un espacio configurado (Sztulwark, 2006) en la ciudad de Comitán de Domínguez que integra por excelencia una variedad de símbolos, y que él mismo es en sí un símbolo tanto para el pueblo de Comitán como para los indígenas tojolabales, ése es la Plaza de La Pila. El barrio del mismo nombre colinda con la pequeña zona céntrica de la ciudad y es uno de sus nueve barrios antiguos. Argüello (1981: 13-14) en su historia oficial escrita -contradictoria y ambigua-, dice que éste es el sitio fundacional y por consiguiente donde se ubicó el primer asentamiento poblacional que dio lugar a la actual ciudad.

Que un grupo de españoles acompañado de algunos indígenas de la región se dedicaron a recorrer los bosques y las montañas cercanas, cuando de pronto descubrieron las huellas de un león, las siguieron prestos a dar muerte a la fiera, pero cuál no sería su sorpresa, al ver que el león los había conducido a una fuente que manaba de entre las rocas y en la cual abrevaba su sed. Los españoles le respetaron su vida, retirándose sigilosamente del lugar fueron a dar parte, tocóse a reunión y se participó a todos del 
hallazgo. El júbilo fue general, acordándose ahí mismo que en el lugar donde manaba el agua, que ellos necesitaban para fundar, se levantase una fuente monumental, y sobre de ella, como símbolo; la estatua del león.

Este texto asigna aspectos inverosímiles respecto a los conquistadores, de hecho, se trata más bien de aspectos que caracterizan a los pueblos originarios: magnanimidad (le respetaron su vida), relación dialógica con la naturaleza (el león los había conducido) y sentido comunitario (tocóse a reunión y se participó a todos... acordándose). En nuestras indagaciones pudimos escuchar una variedad de narraciones que son elementos constitutivos de la memoria de los habitantes de esta ciudad, que tienen ciertas semejanzas a la anterior pero con elementos significativos sumamente diferentes. En el relato de Ramón hay tal paralelismo con la historia oficial, pero con diferencias muy claras. En este caso se trata de un relato donde "el personaje" principal es el agua.

Esta es la historia que vienen unos indígenas que tienen sus ovejitas y una pastorcita llamada Bernarda pastoreando sus ovejas y se encuentra con el rugiente y no se los devoró. Los animales iban buscando agua y ahí encontraron el manantial cuando miraron el león que estaba tomando agua. Esa agua que hasta la fecha nunca se ha desvanecido. Pero esta niña haciendo su oración y al llegar a sus ovejas se le aparece una imagen, la Virgen de la Lourdes, la que está ahí. Es la nacida de ahí de la Pila. Se hincó y se le afloreció a esa hora la mente: No temas que nada te pasará. Y de ahí ese lugar fue historial. Lo fue a decir con sus abuelos. Cuando llegaron al manantial, ahí estaba el animal otra vez y no lo mataron. Vinieron los indígenas que vivían lejos y fueron a ver, entonces comenzaron a poblar Comitán. Aquí sí podemos vivir, hay agua... empezaron a hacer casitas (13-12-2016).

El barrio de La Pila, identificado como un lugar de historia, es sobre todo un lugar de memoria. La razón fundamental de un lugar de memoria es resignificar permanentemente el tiempo, a diferencia del lugar de historia, el cual detiene el tiempo, lo congela porque lo asocia a un solo discurso estático otorgándole una función de narrativa histórica oficialista. Ambos bloquean el trabajo del olvido, uno en forma dinámica y el otro de forma estática (Aróstegui, 2004; Nora, 1997).

Los indígenas tojolabales han erigido a la plaza de La Pila como un lugar de constantes rememoraciones, a la vez de establecerlo como un punto fijo y tradicional de encuentros y congregaciones a lo largo del año. Allí hacen sus preparativos para participar y partir hacia las romerías a los poblados de los alrededores o, incluso, dentro de la misma ciudad. Para Ramón Gómez

La Pila está elegida como un centro de reunión, porque es el centro donde el primer lugar fue señalado por Dios, el manantial... Ese centro lo llamaron como un centro, como le dijera, como le decimos "Santuario", un lugar santo. Desde esa fecha ahí hacían sus reuniones ya los mayas, iban a celebrar... Era montaña, ahí está el manantial. Y se respeta el agua, porque ve usted, increíble que en un cerro brotó el agua. ¿Por qué no brota aquí abajo? Ya ves que es cerro, en el cerro brota el agua. Es por eso que en ese lugar se reúnen, es la historia de por qué se reúnen (13-12-2016). 
Se aprecia la trascendencia del agua y el sentido de sacralidad conferido al sitio donde brota. Esto, además de corroborar lo dicho por Ramón, concuerda con lo expuesto por Pérez-Taylor (2002: 37), cuando analiza el punto de partida de las prácticas tradicionales en sitios pletóricos de significado que permiten "la conmemoración del pasado a través de la participación del hombre con la naturaleza. Ésta se convierte en la esencia que unifica la práctica y la tradición".

En este mismo sentido, las fiestas patronales y romerías nacen en un lugar imaginario y están siempre conmemorando el pasado. Ramón, continúa:

Bueno, ahora ya no se hace ritual, nada más juntas y cuando vamos a romerías. Ahí nos reunimos todos, tocamos tambor, el kiosco, de ahí vamos a la iglesia, salimos. Antes se quemaba cohete, se hacían oraciones, se rezaba, se ponían velas cerquita del manantial y se ponían velas dándole gracias a Dios, que Dios es agua. Eso lo hacían antes y uno de ellos era mi bisabuelo. Tocaban tambores y danzaban alrededor del manantial. Ese lugar es santo, porque ahí nació el agua y Comitán no tenía agua (13-12-2016).

De esta manera remarca que el agua que brota en la plaza es el elemento fundante, $y$ al cual lo identifica directamente con la divinidad. En nuestras indagaciones tuvimos otras impresiones que coinciden con lo antes dicho y, añadiendo otros motivos colaterales, concuerdan en el nacimiento del agua como el elemento clave y el motivo por el cual los tojolabales eligen a la plaza de La Pila como lugar propicio para salir a sus romerías. Melecio Jiménez ${ }^{11}$ argumenta el por qué:

Aquí es nacimiento del agua. Este es ya el centro de todo. Pues yo creo, si antes sí dicen que esta parte es pura agua. El agua es sagrada, pues ahí está el ojo. Significa ja' en tojolabal. Hace tiempo aquí nace el agua. Aquí cuando vinimos de esta Cañada, aquí la iglesia; todos vienen aquí, todos los santos que tenemos, esas banderas que manejamos. Aquí todo queda guardado, aquí en la iglesia (13-12-2016).

Aparecen aquí nuevos elementos simbólicos que se concentran allí: la iglesia, los santos, las banderas; pero el nacimiento del agua -en su sacralidad- hace que el lugar sea "centro de todo". José Hernández ${ }^{12}$ dice que:

De aquí parten cuando vienen a todas las romerías, toda la gente que viene y se van para el templo. Debe tener su contenido... por el agüita que nace... es que aquí pasa un río, y nace ahí donde está el kiosco. De ahí continuamente está el agua borbollando, pero de ahí jsaber qué rumbo lleva! De aquí salen, de aquí... es un lugar santo, por el arroyo

11- Melecio Jiménez Pérez se encontraba junto con su esposa Trinidad Sántiz Sántiz descansando en el parque de La Pila; ambos son tojolabales y trabajan la tierra en la colonia Justo Sierra, del municipio Las Margaritas. Ambos tienen 48 años de edad y todos los años participan en las romerías que se inician en La Pila.

12- José estaba con su hermano Antonio Hernández, pobladores mestizos de Comitán que trabajan como boleros (limpiabotas) a un costado de la Plaza de La Pila. Tienen 75 años y 71 años de edad respectivamente. Nos ofrecieron informaciones relacionadas con los elementos que hacen que este Barrio sea el centro de reuniones tojolabales y de partida para las romerías. 
- Revista de Ciencias Sociales y Humanidades. ISSN-P: 0188-9834 ISSN-E:2395-8669.

que pasa aquí. El agua es sagrada. Ellos, por la vertiente de agua que hay y nadie puede saber cómo viene, de dónde viene esa agua. Este lugar ya es legendario, toda esta cosa. (13-12-2016).

El agua se vuelve a identificar como el motivo principal de la sacralidad del sitio y como centro de congregación para eventos religioso-espirituales, añadiendo ahora otro elemento de la naturaleza: el árbol de la ceiba. Octavio Aguilar ${ }^{13}$ expresa:

Es que aquí hacen juntas, por ejemplo, si van a ir a una peregrinación hacen junta unos ocho días antes para ponerse de acuerdo a qué hora van a salir, comprar tal vez los cuetes, las velas y todo eso. Cooperan ya para esa compra. Ya de ahí dejan la fecha para cuándo van a salir... Hay una fuente de agua que nace, que emerge. Aquí es el lugar de reunión, por el significado que tiene San Caralampio para ellos, la ceiba y todo eso. Ya es un lugar, un centro de reunión aquí ya... aquí se reúnen y porque también brota el manantial (13-12-2016).

Se refrenda al sitio como punto de reunión y de preparativos para las romerías. El motivo se consolida: se debe a la presencia del manantial y la ceiba a las que se asocia la presencia de San Caralampio, elemento simbólico-eclesial. Para Genaro Hernández ${ }^{14}$ :

Es que es el centro de reunión de toda la gente que viene a los diferentes municipios. Tiene algo especial el lugar porque ahí había un arroyo en aquellos tiempos, y alli bajaban los animales a tomar el agua. Pero en estos tiempos ya es muy diferente. Allí se juntan todos, porque ahí está el Santo Patrono de San Caralampio, ahí se guardan todas las banderas y la tradición de todo lo que traen. Es el santo patrono de Comitán y de todos los pueblos indígenas (14-12-2016).

A pesar de los cambios identificados al paso del tiempo, Genaro, siendo tojolabal, aduce que San Caralampio es el santo patrono de Comitán y de todos los pueblos indígenas. El agua, conjuntamente con las banderas "y la tradición de todo lo que traen" (el conjunto de las prácticas que acompañan: rezos, música, velas, incienso, quedan allí), conforman el conjunto de símbolos que refuerzan la memoria del sitio como un lugar sagrado, sin importar que "en estos tiempos ya es muy diferente". Con un pequeño giro muy revelador Alberto López ${ }^{15}$ complementa la imagen de las prácticas asociadas: Ah, porque el que

13- Octavio Aguilar es indígena maya tojolabal de 71 años de edad. Actualmente vive con su familia en el Barrio de El Cedro en Comitán. Anteriormente era de una colonia que se llama Yalumá y luego en Jusnhajab', pero “ya tiene muchos años" que viviendo en la ciudad.

14- Genaro Hernández Hernández es indígena maya tojolabal de 43 años de edad. Nació en la colonia tojolabal de Yalumá y actualmente se encuentra viviendo con su familia en el barrio de Tepeyac, cercano al Barrio de El Cedro en la ciudad de Comitán. Trabaja como barrendero y otros servicios comunales, específicamente en el Barrio de La Pila de la ciudad.

15- Alberto López Velazco, tojolabal de la colonia de Lomantán, en el municipio de Las Margaritas en la llamada Cañada Tojolabal, tiene 85 años de edad. Se dedica a trabajar la tierra y anualmente asiste a las fiestas patronales y romerías. Nos concedió una entrevista frente al templo de San Caralampio. 
quiere venir a adorar al Señor, a San Caralampio. Aquí lo hacen pues, así está acostumbrada la gente. Pues así lo hicieron desde más antes. Aquí está la ceiba, ese árbol que lleva años, flor y vela se le ponen, de gran significado por la sombra que nos da (14-12-2016).

Aunque la forma lingüística es hablar en tercera persona, debe entenderse: "aquí lo hacemos", pues Alberto se encontraba allí participando; "así estamos acostumbrados" o "es nuestra costumbre" como gente debido a que "así lo hicieron desde más antes". Pero en esta ocasión vemos cómo la ceiba también es sujeto de reverencia y de ponerle "flor y vela". Esto es que la sacralidad está remarcada no sólo por un factor, sino por la constelación de los elementos presentes y por la renovación de las prácticas y costumbres.

Este sentido es que se corrobora una y otra vez por parte de quienes sí tienen una respuesta argumentativa, a la plaza de La Pila, con su iglesia de San Caralampio, como lo expresa Agustín Pérez" ${ }^{16}$, como "el sitio indígena" (14-12-2016). Hay gente que no sabe, pero quienes nos ofrecieron el motivo concuerdan en remarcar la constelación de elementos donde el agua aparece como lo principal, asociado a la presencia de la imagen de San Caralampio, a la ceiba y las banderas (mismas que son la representación de cada una de las comunidades participantes).

Aquí el "nacimiento del agua", como elemento fundamental de la naturaleza, propició que La Pila fuese el lugar especial que es para los indígenas mayas tojolabales y, junto con ellos, para muchos pobladores de la ciudad de Comitán; lugar de congregación para partir a romerías que constituyen eventos renovadores de los lazos con otros sitios sagrados de la ciudad y de la región, en espacios territoriales de otros pueblos indígenas.

\section{El sentido de los símbolos empleados en las fiestas patronales y las romerias}

San Martín (1999: 140) sostiene que: "la cultura es el acto creador que extrae el sentido inherente a las cosas"; acto mismo que nos permite aprehender las cosas y mirarlas. Para que algo pueda existir como cultura debe adquirir un sentido

En el caso de los tojolabales, éstos renuevan el acto creador de sus romerías, refrendando el sentido de su congregación en la plaza de La Pila. Ramón Gómez nos aclara: "las romerías es cuando se va en peregrinación en un viaje largo o distante y es donde se llevan el tambor, carrizos y cuetes y se hincan, rezan a pedirle [al santo patrono] que haya de todo. Las demás son fiestas patronales; son otras cosas, son cultos que se le va a rendir a los santos patronos" (25-04-2016).

Reconocida esta distinción, retomemos las prácticas y acciones realizadas por los tojolabales en la ciudad de Comitán. Frente al templo de San Caralampio, lugar en que guardan y protegen los símbolos que llevan a sus romerías, como se ha señalado arriba, se reúnen sin distinción entre quienes habitan en el espacio urbano y quienes llegan de localidades rurales para organizar estas peregrinaciones y para iniciarlas. El conjunto de símbolos incluye las banderas y estandartes de las localidades participantes, e

16- Agustín Pérez Hernández, habitante tojolabal del Barrio de El Cedro y con 71 años, asiste cada año a las romerías que tradicionalmente se organizan en la Plaza de La Pila. Estando allí nos dio posibilidad de diálogo. 
- Revista de Ciencias Sociales y Humanidades. ISSN-P: 0188-9834 ISSN-E:2395-8669.

imágenes de los santos, los cuales son acompañados con tambores ${ }^{17}$, pitos o $\operatorname{carrizos}^{18}$, $\operatorname{caracoles}^{19}$, cachos $^{20}$, cuetes, velas, aguardiente, incienso y flores.

El otro sitio de encuentro es conocido como Chumís ${ }^{21}$, que es precisamente de donde se sale para peregrinar hacia San Caralampio y que, igualmente, es punto de salida para otras romerías, como la de San Bartolo del municipio de Venustiano Carranza y la que va a Padre Eterno en la cabecera municipal de La Trinitaria. Igualmente allí parten para asistir en procesión hacia algunas fiestas patronales de la ciudad, tales como las de San Antonio, San Francisco y la Virgen de la Paz.

Ramón nos aclara: "Se elige algunas veces la salida desde el Chumis, porque en ese lugar hay una cruz. Esa cruz fue puesta por nuestros antepasados. Esa cruz es para evitar el maleficio, los malos espíritus que entren al pueblo y dar ritos, gracias porque llueva, porque no haya vientos, se encendían velas, ahora ya no la encienden" (13-12-2016).

El Chumis es un árbol muy antiguo y de pequeña talla, ubicado a las afueras de la ciudad de Comitán, a unos $3 \mathrm{~km}$ de la plaza de La Pila, en la salida hacia la Cañada Tojolabal ${ }^{22}$.

Previo a emprender el camino, en cualquiera de los dos sitios, se hacen dos largas filas de abandera$d o s^{23}$ que, avanzando en contrasentido una de otra, saludan las respectivas banderas y estandartes besando las puntas. Ramón nos expresa el sentido diciendo que es un: "símbolo de respeto y tienen que pasar asi todos, todo, todo, símbolo que quiero paz. Vamos a celebrar esta entrada de flores, la romería o lo que le llamen con símbolo de paz, no queremos guerra, ése es el sentido" (20-04-2016). Luego se arrodillan todos y besan la tierra pidiendo permiso para iniciar.

José Alfredo Gordillo ${ }^{24}$, indígena tojolabal nos dijo primero su sentir al participar en las romerías: "Llevo muchos años seguidos, se siente uno muy feliz viniendo acá, se reviven las tradiciones cada año y lo bonito es que no se van olvidando sino que se van concentrando y reafirmando cada vez más"; y entonces remata: "Llevamos las banderas, símbolo de todas las comunidades participativas, la unión de todas las comunidades de la fe cristiana" (13-05-2016). Son estos representantes de las comunidades tojolabales

17- Llamados en tojolab’al: wajab’ales, los cuales son encabezados por uno mayor denominado: snan wajab’al.

18- Es un instrumento musical empleado por los tojolabales en las romerías o peregrinaciones que se toca acompañando a los tambores. Es elaborado con carrizo, especie de bambú, y de ahí viene el nombre. Su sonido es similar al de una flauta dulce pequeña.

19- Son caracoles grandes extraídos del mar y que emiten un sonido grave en armonía con los demás instrumentos musicales.

20- Es un cuerno de ganado vacuno que, una vez seco se ahueca y emite sonidos agudos como trompetas. Sirven, igual que el caracol para convocar.

21- El Chumis actualmente es un árbol muy pequeño, ubicado a las afueras de la ciudad de Comitán, a unos $3 \mathrm{~km}$ de la plaza de La Pila, en la salida hacia la Cañada Tojolabal. Allí se hacen juntas o reuniones de campesinos e indígenas de la localidad, generalmente tojolabales y es otro punto de partida para romerías. Aquí inicia la "entrada de flores" de San Caralampio en Comitán y las romerías que van a San Bartolo en Carranza y al Padre Eterno en La Trinitaria; e igualmente aquí parten para asistir en procesión hacia algunas fiestas patronales de la ciudad, tales como las de San Antonio, San Francisco y la Virgen de la Paz en La Pilita Seca.

22- Entre las principales comunidades que componen la "Cañada Tojolabal” están: Piedra de Huixtla, 20 de Noviembre, San Caralampio, La Piedad, Buena Vista Bawits, La Libertad, Rosario Bawits, Justo Sierra, González de León, Bajucú, Plan de Ayala, Veracruz, Lomantán, Yaxá, Yalumá.

23- Abanderados son las personas designadas por sus respectivas comunidades para que lleven la bandera que identifica a esa comunidad como participante.

24- José Alfredo Gordillo es indígena maya tojolabal de 44 años de edad, procedente de la comunidad campesina de San Francisco. Participante activo en las romerías que parten desde La Pila en la ciudad de Comitán. 
que llevan consigo y con la multiplicidad de símbolos que reafirman las acciones por el recuerdo y contra el olvido, la solicitud de las bendiciones de la lluvia para la efectiva germinación de las semillas en sus sembrados, que se espera resulten en una fructífera cosecha. Estas banderas llevan grabados los nombres de esas comunidades, así como las imágenes de los santos patronos a quienes se les rendirá culto y veneración a través de rezos.

Unidos a las banderas, los tambores son muy significativos para los tojolabales. "Cada colonia trae su grupo de tamboreros, de los alrededores de Comitán: Las Margaritas, La Independencia, Yalumá, Yaxá” (José Alfredo Gordillo. 13-05-2016). El mismo José Alfredo refiere que: "El toque de los tambores significa que estamos hablando con Dios y dándole gracias a Él por sus bondades con nosotros" (13-05-2016), lo que es confirmado por Armando: "Es la tradición que los antepasados nos dejó. Y los toques son por lo mismo para pedir la agüita. Estamos hablando con Dios a través de los tambores y pedimos por las milpitas. Nuestros abuelitos eran tojolabales y lo hacían asî" (13-05-2016). Así que todos evocan a sus ancestros en una continua relación a través del simbolismo articulado a sus prácticas culturales. Es la ancestralidad la que refrenda el sentido a través del conjunto de símbolos a la práctica cultural.

Las piezas de tambor tienen nombres específicos tales como: Cortesía, que se toca antes de iniciar, al principio, durante y al finalizar la peregrinación. Está también San Pedro o San Pedrano, El mero tojolabal, el Comiteco y Altamirano. Todos estos nombres remiten a la gente de diferentes lugares. Estas piezas musicales van cambiando a medida que van caminando su largo viaje y de acuerdo a la adoración del santo homenajeado.

Símbolos de diálogo con la divinidad, los tambores están encabezados por un pito, que convoca a la unidad, la paz y la reconciliación entre los participantes, como ofrenda a Dios. Así mismo vienen los cuetes que, además de anunciar la peregrinación, emulan los truenos que avisan la proximidad de la lluvia (Nájera, 2009).

Cuando llegan frente a los templos de los barrios o comunidades en donde se encuentra el santo patrono o frente a los sitios donde hay una cruz grande de madera, es momento para hacer un acostumbrado ritual tradicional. A las cruces de madera le dan tres vueltas todos los participantes, con sus instrumentos musicales. Ramón nos ofrece una explicación:

Venimos ya luego a donde está el Templo, ahí está la Cruz, le damos tres vueltas, eso es lo que digo yo [que] lo están acabando. Mire, esas tres vueltas de la Cruz, la primer vuelta con la pieza que se llama Cortesía, que significa Gloria, y echándole su medio incienso, adelante va el cohete, luego el incienso y luego el tambor. Atrás de los tambores van las banderas. La primera vuelta es anuncio de la muerte de Jesús, que en esa cruz iba a morir. La segunda vuelta es la muerte de Jesús que murió en esa Cruz. La tercera vuelta es la resurrección de Jesús que en esa cruz murió y resucitó, entonces entramos a la iglesia, ya va el canto. Eso es un símbolo del tojolabal que le da agradecimiento a Dios porque en esa cruz murió. [Cuando se ha concluido con las vueltas] Entonces se van a sentar las gentes y comían sus comiditas y su poco de tragos en unos vasitos, no eran copitas ni eran caballito, no, eran unos vasitos de barro a poner bien el altar con flores, velas y vamos a danzar y van a echar sus copitas" (20-04-2016). 
El aguardiente es un elemento más del conjunto de elementos que configuran el ritual.

Visto todo lo anterior, concordamos con San Martín (1999: 188), que nos conduce a reflexionar en que la cultura "es efectuación, creación de un sentido con vistas a satisfacer los deseos humanos. Para que la creación cultural sea tal, ya hemos visto que es necesario que sea solidariamente asumida, una vez sedimentado el sentido". Estos deseos humanos son los que dirigen al colectivo participante a realizar la acción concreta de las romerías, con toda la cauda de elementos y símbolos, como forma de renovación del sentido del mundo heredado.

\section{Fiestas patronales y romerías con la participación tojolabal en Comitán y poblados circunvecinos}

Hemos reconocido la presencia tojolabal en el espacio urbano de Comitán, así como a la plaza de la Pila como el centro de sus congregaciones y encuentros para partir a sus romerías y a las fiestas patronales a que acuden; hemos identificado también los elementos simbólicos que confluyen y se hacen presentes para tales actividades, hagamos ahora un reconocimiento precisamente a tales romerías y fiestas. Primeramente debe destacarse que los tojolabales alimentan el recuerdo de sus antepasados en dichas actividades, en sus costumbres y tradiciones, así como también en muchas de sus actividades cotidianas.

Poseedores de una "memoria ancestral" (Walsh y García, 2010) vinculada a sus antepasados, con ello dan una configuración particular a su "memoria colectiva" (Aróstegui, 2004). Así refuerzan sus sentimientos de pertenencia colectiva, sintiéndose impulsados a la realización y participación en las prácticas culturales como herederos de una tradición. Estas prácticas, entre las que están las fiestas patronales y romerías, las realizan entremezclados con pobladores mestizos de Comitán y con gente de otros pueblos originarios de la ciudad y la región.

Los tojolabales han sido sujetos protagónicos permanentes de estas actividades. Cada una de ellas ha devenido un acto específicamente cultural al dotarlos de sentido. San Martín (1999: 177) dice que: "el acto específicamente cultural es el acto creador de sentido". Y para que haya una creación de sentido es necesario que ya existan vidas pautadas con un cierto sentido. La gente de este pueblo lo que ha hecho es renovar su sentido desde una lógica de comprensión racional conducente a dar cuenta con legitimidad de sus vivencias culturales.

Las romerías más sobresalientes que hemos podido observar durante los últimos tres años, son las de San Caralampio en Comitán de Domínguez (febrero), el Señor de Tulancá o del Trapiche en el municipio de Amatenango del Valle (marzo-abril), Santo Tomás en el de Oxchuc (abril), San Bartolo en el de Venustiano Carranza (abril), Padre Eterno en el de La Trinitaria (mayo) y San Mateo Ixtatán en Huehuetenango, Guatemala (septiembre). Las primeras se realizan en el período de secas, previo a la siembra, en tanto que la de San Mateo se lleva a cabo cuando la milpa ya ha crecido y dado sus frutos.

Asociados a estas romerías se asiste a múltiples fiestas patronales: Cristo de Esquipulas en el barrio Nikalokok en Comitán (enero), San Caralampio en Jusnhajab' (febrero), Virgen de la Candelaria en Socoltenango (febrero), Señor de las Tres Caídas en Chihuahua cerca de La Trinitaria y en Quijá en Comitán (marzo-abril), San Carlos en la cabecera municipal de Altamirano (abril), San Isidro en Ti'nhajab’ (mayo), Padre Eterno en Yaxá y su recorrido por las comunidades de la "Cañada Tojolabal” (mayo), San- 
ta Margarita de Cotona en la cabecera municipal de Las Margaritas (julio), Santo Domingo en el barrio Centro de Comitán (agosto), Virgen del Rosario en el barrio de Yalch'ibol (octubre) y Santa Teresita en el barrio de la Cruz Grande (noviembre).

En años recientes (en los últimos quince años aproximadamente) se han incorporado los viajes a nuevas comunidades que son identificadas como "de nueva creación" para celebrar sus santos patronos: Virgen de la Candelaria en el barrio de la Candelaria en Comitán (febrero), San José en el barrio de San José Obrero (abril), San Pedro Mártir en la Colonia Los Riegos (abril), Día de la Santa Cruz en el barrio de la Cruz Grande (mayo), San Antonio en el barrio del mismo nombre en Comitán y en San Antonio Ogotzil (mayo), María Auxiliadora en el barrio Linda Vista en Comitán (mayo), Santo Domingo en la colonia Los Laureles y en la de Las Granadas (agosto), San Miguel Arcángel en el barrio de San Miguel en Comitán (mayo) y en San Miguel Tỉnhajab' (septiembre), San Rafael en San Rafael Jokom en Comitán (septiembre), Virgen Corazón de María en la colonia Yalumá (agosto) y San Francisco de Asís en la colonia El Rincón (octubre), Virgen de la Paz en el Fraccionamiento La Paz del barrio La Pilita Seca en Comitán (noviembre), Niñito Jesús en Bajucú, Lomantán y Zaragoza de la Montaña (diciembre).

José Alfredo Gordillo, indígena tojolabal antes mencionado, nos expresa y reafirma el sentimiento de pertenencia colectiva que le provoca participar en estos eventos diciendo que: "Es en la participación de cada año que se reviven las tradiciones. Se van reafirmando cada vez más (13-05-2016). Cuando conversamos con Genaro Hernández nos dijo: "Nuestros antepasados dicen: deben asistir aunque sea a una romería al año" (25-06-2015).

Cuando preguntamos por qué caminan largas distancias en sus romerías, sus respuestas remiten a un mismo sentido de ancestralidad que se articula con su religiosidad. Por ejemplo, Caralampio Velasco ${ }^{25}$ asume que es: "Por la devoción y la creencia. Nuestros abuelos nos lo enseñaron" (20-02-2017). Por su parte Caralampio Jiménez, junto a su esposa Concepciona ${ }^{26}$, plantea: "Pues Dios está mirando que ahí vamos, nos lo enseñaron los antiguanos, los viejitos. Pues Dios está mirando; que si no vamos, pues está jodido" (2002-2017). Él nos expresa no sólo la lógica de creación sino también de reafirmación de horizontes, en el sentido que la ruptura de las prácticas de religiosidad les ubicaría en condiciones indeseadas.

Isidro Hernández, corroborado por su hermano $\operatorname{Carlos}^{27}$ que asentía, dijo: "Ésa es una promesa de cada quién que se le hace al santo; era una devoción espiritual. Los abuelitos caminaban también" (20-02-2017) y así lo corrobora Roberto Jiménez ${ }^{28}$ : "Caminamos porque así estamos acostumbrados. Es nuestra costumbre de llegar hasta allá, hasta Nuestro Señor. Esa costumbre nos la dio nuestros abuelos cuando vivían y nos exigimos venir a pagar nuestras promesas. Así caminaron nuestros abuelos" (20-02-2017). El hacer promesas al respectivo santo es una decisión personal de los "romeros" y viene siendo otro elemento que motiva los viajes largos o caminatas. Estas expresiones que remiten a la realización de una práctica religiosa heredada, involucran al caminar, que se constituye en una acción muy significativa en la cultura tojolabal.

25- Caralampio Velasco tiene 70 años. Entrevistado en el Barrio de La Pila en Comitán. Es indígena tojolabal participante en las romerías, viene del municipio La Independencia.

26- Caralampio Jiménez Álvarez y su esposa Concepciona Jiménez Jiménez tienen ambos 67 años. Indígenas tojolabales de González de León. Participantes en las romerías que parten desde el Barrio La Pila en la ciudad de Comitán.

27- Isidro Hernández y Carlos Hernández Moreno. Son indígenas tojolabales de la Colonia Señor del Pozo y del Barrio de San José Obrero, con 74 años y 80 años respectivamente. Participantes en la romería de San Caralampio 2017.

28- Roberto Jiménez Pérez es indígena tojolabal de 50 años de edad y participante en la romería de San Caralampio. 
Ramón refiere que: "Es necesario caminar porque vamos a darle las gracias a Dios. Es un modo de agradecimiento". Luego desde una lógica de cambios y modernidad explica que los ancestros caminaban: "Porque no tenían cómo conducirse en aquel tiempo. No había de estas cosas que hay ahorita". Ahora se usan vehículos, en algunos casos hasta el sitio mismo y en otras bajándose previamente para hacer un tramo del recorrido a pie.

Para los tojolabales el sentido de su participación en estas celebraciones religiosas es ir a pedir principalmente por el agua y, conjuntamente con ello, también se hace como realización de una promesa, para agradecer y pedir por salud, entre más. Armando Aguilar y Gilberto Alfaro ${ }^{29}$ participan todos los años con devoción para: "Pedir por la salud de uno, pedir el agua para la milpa; que mande el agüita, para que haya pues comida" (13-05-2016).

Por su parte Agustín Pérez, conciso, afirma: "Nosotros salimos a romerías por nuestras comidas, nuestros frijoles, por nuestro maicito, por el agua, queremos agua para allá, y Margarito igual sentencia: "El peregrinar es para darle gracias a los dioses y pedirles agua, alimento, salud". Estos argumentos nos remiten a la idea de que lo sagrado, la práctica tradicional y su relación con la naturaleza, son elementos estrechamente imbricados, lo que en un ámbito de labor agrícola cobra una relevancia mayor. La participación tojolabal en las romerías de mayor antigüedad está bien conectada a su ciclo agrícola y a los tiempos de lluvias. Esto viene a ser el móvil principal e impelente que les conduce a participar en las fiestas patronales y las romerías con sus peregrinaciones.

Para comprender mejor estas festividades hagamos un desglose de la participación tojolabal en la festividad de San Caralampio. Los tojolabales conjuntamente con la población de Comitán tienen a los festejos de este santo, en el mes de febrero, como la festividad popular-cultural-religiosa más concurrida y de mayor participación espontánea de la ciudadanía (la gente que gusta se suma a la romería con velas y flores, vistiendo trajes regionales, disfrazados, montados a caballo, haciendo verbena y carnaval con música y carros alegóricos). Esta "entrada de flores" es encabezada por los tojolabales.

La historia oficial plantea que la imagen del santo Caralampio ${ }^{30}$, muy venerado en Grecia y reivindicado por la iglesia griega ortodoxa, llega a Comitán alrededor del año 1850, aunque Basauri (1931) apunta su llegada hacia el año 1862. Para Román (2005) esta ciudad se ha convertido en su segunda patria. Según Argüello (1981: 112) "los comitecos tienen en San Caralampio un protector y un juez, ya que el mártir intercede por ellos con la mejor de las voluntades, para su alivio"; pero enfáticos Basauri (1931) y Ruz (1982) sostienen que este santo es particularmente significativo para el pueblo indígena maya tojolabal. José Alfredo Gordillo no tiene reparo en decir que "Ésta es una fiesta indígena, mayormente tojolabal" (13-05-2016).

Ramón, por su parte, ofrece algunos recuerdos de cómo la fe en San Caralampio los ha convocado en los momentos difíciles:

29- Armando Aguilar García y Gilberto Alfaro Aguilar son tojolabales de Yaxá y Yalumá de 67 y 73 años respectivamente. Tamboreros informantes en la peregrinación al Padre Eterno en Trinitaria en su salida desde La Pila.

30- La historia oral dice que la imagen de San Xaralambos (en griego) llegó a Comitán a través de un soldado de Santiago, Cuba, donde se veneraba el santo. El comiteco Raymundo Solís, es el impulsor del culto de San Caralampio, en el barrio de La Pila y en 1862, el gobernador de Chiapas, Juan Clímaco Corzo, declaró oficialmente la festividad del santo. 
Sabemos agradecer que gracias al San Caralampio tenemos agua, tenemos vida. Cuando hay alguna necesidad se le reza a San Caralampio. Nosotros lo hemos vivido porque por ahí alrededor de unos 45 años atrás yo estaba recién casado con mi esposa y vino una sequía tremenda, y el pueblo se levantó y dijo ¿qué hacemos? Vamos a sacar a San Caralampio, fuimos, nos juntamos todos, así como hicimos ese día del 10 de febrero, con cohetes, con banderas y lo llevamos por todas las milpas, era un desierto, no había agua ni nada. ¡Cómo fue que al entrar a la iglesia se desata los grandes aguaceros! Miren ¿Qué precioso! Admirable. Al entrar a la iglesia como que alguien hubiese quebrado algo y comienzan los aguaceros. Y hubo grano, hubo semilla y la gente andaba llorando, y ya los papás tristes porque no había qué comer. (20-04-2016).

Austreberto Díaz ${ }^{31}$, participante en la romería cada año, nos comenta que: “Las peregrinaciones vienen de las Rancherías y se reúnen en el Chumís. Se llama Chumís que tiene más de 100 años, está como a tres km de aquí. Es un punto de reunión desde que inició la tradición. Lo que pasa que ese Chumís le daba sombra a la gente anteriormente. Anteriormente de ahí venían miles y miles de gentes". Teresa Mora hablando de la génesis de la peregrinación asegura que: "Un cronista dijo que esta peregrinación se hace desde 1910 y se hace en honor al martirio de San Caralampio el día 10 de febrero". Según ella: "Los indígenas tojolabales vienen de todas las comunidades a rendirle culto, pues ya ves que todos tenemos raíces mayas. En la romería se ve la religiosidad, pues mucho después de la evangelización conocieron a San Caralampio"(10-02-2015).

El motivo principal de esta romería de San Caralampio lo declaran sus participantes tojolabales: para pedir en sus rezos por la salud de todos, por que cesen las enfermedades, por las lluvias para que generen cosechas abundantes, así como por una economía exitosa para todas sus comunidades. De forma sencilla lo expresa Berta Morales ${ }^{32}$ : "La devoción es venir todos los años a la romería ésta que se le hace. Le pedimos que él nos regale salud para venir el siguiente año, que no nos falte nuestra comidita de todos los días que es lo principal" (10-02-2016). Belisario López ${ }^{33}$ dice que su motivación es: "La peregrinación, la fe en Dios. Le pedimos a San Caralampio que nos de la bendición. Que estemos buenos. A la salud, por toda la familia, los hijos. Por las milpas, los trabajos que hacemos en las milpas" (10-02-2017). Candelaria ${ }^{34}$ dice lo mismo en breve: Le pedimos que estemos buenos, que todo nos vaya bien, mucha salud. (10-02-2017).

Irene López, descendiente tojolabal, expone que su motivo de venir a la peregrinación es: “A agradecerle. Unos a agradecerle nuestras cosechas y también a pedirle que nos proteja en este año de todo lo malo que hay, por ejemplo de las enfermedades contagiosas. Pedimos lluvia para los sembrados. Eduardo Trujillo y su esposa Leticia Domínguez ${ }^{35}$, nacidos en esta tierra y fieles seguidores de este santo, son de nuestros entrevistados durante el desarrollo de esta romería. Ellos dicen que: "Es la fiesta tradicional

31- Austreberto Díaz es comiteco de 67 años de edad. Trabaja en la tienda de veladoras de los frentes al templo de San Caralampio en el Barrio La Pila en Comitán. Participante en la romería del santo que cuenta su experiencia.

32- Berta Morales es descendiente tojolabal tiene 72 años. Esposa de Ramón Gómez y tamborera participante en la romería.

33- Belisario López García es tojolabal de 76 años. Participante en la romería al santo procedente de la colonia Yaxá.

34- Candelaria tiene 70 años y viene desde el municipio de Tzimol a venerar a San Caralampio y traerle sus ofrendas.

35- Eduardo Trujillo y su esposa Leticia Domínguez. Ambos de 72 años y 69 años respectivamente, son participantes comitecos que vienen cada año a la romería de San Caralampio. 
más grande y auténtica de Comitán. Ésta sí es una fiesta de pueblo. Es una fiesta de los pueblos indígenas de Comitán" (10-02-2015).

Basauri (1931: 42) abunda en cómo se hacía la romería alrededor de cincuenta años atrás. Él describe a un gran número de participantes tojolabales: "A esta fiesta concurren todos los indios, llevando muchas y variadas ofrendas: gallinas, borregos, huevos, flores, palmas, dinero". En la entrada del santuario se encuentra el que han denominado "jacal". Debajo de éste ubican a la tradicional marimba, la cual da la bienvenida y animación a los participantes. Guadalupe Gordillo ${ }^{36}$ nos explica que: "Aquí en la región se le llama jacal. Jacal es de raíz tojolabal, de una lengua de los indígenas tojolabales de la región y significa "Enramada". Está compuesta por flores de la región. Se coloca la Flor de San Caralampio, que aquí le llamamos Eques. Los tojolabales le llaman Palpal y esa es la Flor de San Caralampio" (17-02-2015). Teresa Mora nos argumenta que:

A su preparación acuden tres grupos de personas por tradiciones de familias que durante muchos años se dedicaron a este servicio con devoción. El primer grupo son los hombres que elaboran el armazón de madera o de hierro o jacal. El segundo grupo se va a la montaña y trae las ramas verdes de laurel fresco. Dichas familias invitan a otros colaboradores para que ayuden en la construcción del jacal y a traer las ramas de laurel. Este legado es transmitido por las familias de generación en generación y si muere alguno le siguen sus hijos, nietos, yernos $u$ otros miembros. El tercer grupo está compuesto por mujeres y hombres que traen las flores frescas el día de la peregrinación y el primer grupo que construyó el jacal se encargará de colgarlas. Debajo de este jacal descansan los romeros o peregrinos a su llegada y estarán los músicos que generalmente animan la fiesta con la música de marimba. (28-01-2016).

Corroborando lo antes dicho, Rodrigo López ${ }^{37}$, uno de los miembros de la familia que tradicionalmente organiza el jacal, expresa que: "Somos la familia López, Espinosa, Morales y ya llevamos alrededor de 40 años con esta tradición. Se hace el jacal para alegría del Señor San Caralampio. Las comunidades indígenas traen la flor del Palpal o de San Caralampio, y la flor de platina que es ésta. Esta es una devoción que le hacemos al santo" (10-02-2016). Augusto López ${ }^{38}$, se une al sentir de su familia y nos dice el motivo de continuar con la tradición: "Porque los antepasados, por decir cien años atrás nos lo dejaron, si yo tengo 73 años y desde bien chavo venía yo a ayudar aquí. Quiere decir que más o menos tiene más de 100 años esto aquí. Es tradición, para que se vea bonito, verde" (01-02-2017). El legado sigue de generación en generación por esa relación continua con los antepasados.

Entonces el día 20 de febrero vienen de todas las comunidades indígenas vecinas, de la zona urbana de Comitán y de otras ciudades y regiones de Chiapas y de México para agradecer al santo. Se hacen filas para recibir cada cual un ramito de hinojo o romero con un trozo de vela. Con ello en las manos caminan frente al santo y lo pasan por su manto, y lo besan y eso lo llevan a sus casas como de costumbre.

36- Guadalupe Gordillo es comiteca y tiene 55 años y es servidora en el templo de San Caralampio en la ciudad de Comitán. 37- Rodrigo López Gómez tiene 63 años de edad. Es miembro de la familia que organiza el jacal dedicado a San Caralampio cada año.

38- Augusto López Argüello tiene 73 años. Viene a traer y colocar ramas verdes en la galera de San Caralampio por tradición familiar que se transmite de generación en generación. 
Caralampio Velazco, indígena tojolabal nos amplía lo antes dicho: "Pues la velita es para que llegando a nuestra casa la encendamos a nuestros santos a la imagen y el hinojo es para tomarlo porque es remedio. Esa vela significa que es la luz del mundo como una devoción" (20-02-2017). Luego Roberto Jiménez, también tojolabal, explica que: "Es que ante cualquier enfermedad lo hervimos en una calderita y lo tomamos para levantar nuestra defensa, sanar la cabeza y quitar el dolor de nuestro corazón y la velita la encendemos en nuestro altar al santito" (20-02-2017). Y en ese mismo sentido Gloria Alfaro sostiene que: "Nuestra tradición es nada más porque como creemos en él, entonces esta yerba la tomamos y nos limpiamos con San Caralampito. Lo llevamos a la casa y la vela la encendemos allá. Depende de la devoción de cada uno" (2002-2017). Todo lo anterior remite a una misma lógica de sentido, una manifestación de fe con el fin de lograr el bienestar físico, material y espiritual tanto individual como colectivo.

El conjunto de celebraciones antes dicho y con incidencia mayormente en el espacio geográfico urbano nos habla de un intenso deseo por seguir construyendo comunidad, sacralidad y una nueva lectura sagrada de la relación con la historia y con la naturaleza como elementos clave que integran y que le dan continuidad al modo de vida de los tojolabales. Las romerías antiguas corresponden a un ciclo calendárico muy particular, así como al tejido de relaciones con otros pueblos en la configuración de un territorio vivido como relaciones y como una constelación de sacralidades.

$\mathrm{Al}$ conjunto de fiestas los tojolabales le han asignado un valor cultural central, mismas que le han dado la posibilidad de definir sus fronteras identitarias respecto a otros grupos poblacionales de la región y que además significa su tiempo de encuentros, de cohesión social, de convivencias y la promulgación de una vida en comunidad relacionados en un territorio con el conjunto de localidades vecinas.

De igual forma sus participaciones en las fiestas patronales y romerías ha traído consigo el ser reconocidos, lo que se traduce en un reconocimiento expreso de su existencia consolidada mediante estos espacios colmados de solemnidad y sacralidad y a su vez de diversión. En ellos se consolida el grupo manifestando abiertamente su religiosidad acudiendo, como lo hicieran sus antecesores, a las imágenes de los santos patronos de los distintos fragmentos de un territorio habitado culturalmente.

Para algunas familias tojolabales estas celebraciones marcan un tiempo eficaz de congregaciones y encuentros periódicos entre sus miembros. Mientras que en la esfera de lo lúdico éstas les permiten participar en las actividades de entretenimiento público con sus amigos, paisanos y familias cada año. Al mismo tiempo, dinamizan elementos de índole social y económica participando en algunas transacciones comerciales propiciadas por la fiesta y en la adquisición de bienes de consumo con artesanos y comerciantes ambulantes o fijos.

\section{Adecuaciones tojolabales a su participación en las romerías y fiestas patronales}

Siendo que los tojolabales no tienen un centro cultural ceremonial ancestral y propio, las fiestas patronales y las romerías se constituyen en la única modalidad festiva de este pueblo que trasciende los límites de las diversas localidades. En los diálogos que hemos sostenido con las personas tojolabales se nos dice que sus condiciones tanto físicas, como económicas y políticas, así como la intervención de algunas 
"sectas religiosas" ${ }^{39}$ por la actitud proselitista y los señalamientos críticos en un entorno donde los señalamientos negativos son considerados como una forma de mal social, han provocado la disminución de la participación de peregrinos en el ritual. Igualmente las peregrinaciones en la mayor parte de los casos ya no alcanzan los seis o nueve días de recorridos que antes hacía, pasando por puntos intermedios identificados, asociados a grutas y cerros sagrados, sino que van directo en transportes, en ocasiones haciendo algún alto momentáneo en alguno de esos puntos, para continuar e, inclusive, regresar el mismo día.

En este sentido algunos de nuestros informantes claves como Guadalupe Gordillo sostienen que la disminución participativa se debe a: "que mucha gente ya se está cambiando de religión. [Y que] los tojolabales están perdiendo sus costumbres, por la intromisión de tanta televisión y de las sectas religiosas que han hecho que se vayan de los católicos para la religión cristiana que ya no creen a ningún santo" (17-02-2016). Eduardo Trujillo al igual plantea que:

"Se ha cortado mucho la participación en las peregrinaciones, antes era mucho más grande. Pero se ha dividido mucho las sectas religiosas. La intervención del capitalismo ha hecho que la participación de los indígenas en la peregrinación disminuya. Porque el apoyo económico de muchas sectas que no lo tiene la religión católica ha jalado muchos intereses, religiosos desde luego pero el apoyo económico que tienen las sectas extranjeras les brindan otros beneficios que la católica no las tiene" (10-02-2015).

Aunque esto no lo podemos confirmar con el alcance de nuestro estudio, lo que sí atestiguamos y que es algo a lo que tal vez no llegan tales impactos negativos es a la cantidad creciente de sitios de visitación. $\mathrm{O}$, ¿es que acaso más bien es como una forma de redirigirse precisamente por tales impactos? Lo que nosotros sí hemos podido observar es que los "romeros" tras congregarse en la plaza de La Pila, frente al templo de San Caralampio, de allí viajan en transportes y llegando a cierta distancia deciden bajarse y caminar un pequeño tramo de uno y hasta medio kilómetro rumbo a los lugares sagrados señalados.

La introducción de algunos elementos modernos dentro de las festividades a modo de ferias comerciales y carnavales es un hecho incontrovertible, a la vez que polémico. Así lo entiende Gilberto López ${ }^{40}$ : "Antes no era como ahora. No había estos juegos tecnológicos modernos ni grupos musicales. Los indígenas están cambiando y se van modernizando. Para que digan que no son indígenas quieren igualarse al mestizo" (13-05-2016).

A pesar los cambios que han podido suceder en dichos eventos, los tojolabales continúan participando cada año en las romerías sin perder sus horizontes de sentido en la realización de dichas prácticas, mayormente referido al sentido comunitario, al de sus relaciones con otros grupos sociales, con la naturaleza y con lo sagrado.

Pudimos constatar que la participación tojolabal en estas festividades es acorde a dichos elementos que les son muy característicos, teniendo como eje vertebrador el elemento más socorrido para referir a

39- Dígase aquí las influencias de las iglesias Presbiterianas, Adventistas del Séptimo Día, Testigos de Jehová, Bautistas, Nazarenos, Pentecostés, entre otras.

40- Gilberto López de 82 años de edad es habitante de La Trinitaria, al llegar a este pueblo el día de la peregrinación al Padre Eterno, nos dio algunos detalles de esta romería. 
su valor fundamental: las relaciones comunitarias, que dan base a su sentido de vida (Lenkersdorf, 1996). Así lo manifiesta Caralampio Velazco: "Nos gusta vivir en comunidad porque hay más contacto, más convivencia también. Pues fíjese usted que solitos pues no es fácil ¿con quién va usted a hablar y divertirse? ¿Con quién va usted a contar? (20-02-2017). En las romerías los participantes comen en común, hay bebidas para todos, lo que les permite reforzar el sentido de unidad y el compartir, así como los vínculos de su existencia y coexistencia con la divinidad, con la naturaleza y con otras culturas con las que interactúan.

Igual resulta para Roberto Jiménez, otro tojolabal: “Nos gusta vivir en comunidad porque andamos más unidos" (20-02-2017). En tanto que para Augusto López, descendiente tojolabal, la cuestión es la unidad pero reforzada con la alegría: "Tenemos la fama que somos muy unidos, sobre todo en estas cosas y más para la alegría de este Barrio" (01-02-2017). De alguna manera esto constata lo dicho por Fábregas (2012: 68), en el sentido que: "Las romerías son el espacio social y cultural de la interrelación tanto comunal como hacia el exterior. Son un momento crucial de la vida del pueblo tojolabal que se reconoce en su unicidad y en sus relaciones externas". Así lo hemos podido confirmar durante el presente estudio, como un aspecto significativo que fortalece las relaciones interculturales y el diálogo conjunto en su propio mundo y el que les rodea.

Otro asunto que evidencia transformación nos lo expone Ramón, al hablar de la incorporación de las mujeres:

Lo que hemos tratado nosotros, con mi esposa, es de rescatar las tradiciones, usos y costumbres y culturas; lo que está a nuestro alcance. Pero vemos desgraciadamente los varones, sin ofender, ya no quieren hacer ya lo que es la cultura indígena, les da vergüenza. Y ¿qué hicimos nosotros?, de tratar la manera que si no quieren los hombres tal vez las mujeres quieran. Pues entonces a conquistar a las mujeres primero. Ya ves que mi esposa ahí va conmigo.

La participación femenina en las romerías como "tamboreras" resulta, en este sentido, novedosa. Mujeres ejecutando los tambores al igual que los hombres tojolabales, cuando nunca había sido esa la costumbre, modifica la imagen de estos colectivos como puramente masculinos.

\section{Conclusiones}

Lenkersdorf (1996: 165) refiriéndose al tipo de eventos que hemos analizado propone: "estas clases de fiestas agregan elementos adicionales a los intersubjetivos, es decir, lo que importa a las comunidades tojolabales es transmitir sus experiencias históricas y educar de manera participativa, a la juventud con respecto al tiempo, la religión y el análisis de la realidad que se vive". Ésta es una forma de transmitir fáctica y oralmente la herencia espiritual y cultural recibida por los antepasados y que las nuevas generaciones, así como sus coterráneos, conozcan la historia vivida, los elementos que dan cohesión a su pueblo y lo vivido como sentido de existencia.

En el caso de la presencia activa tojolabal en estas festividades, queda mayoritariamente restringida en los tiempos de nuestro estudio a las personas adultas, mientras que los jóvenes parecieran no interesarse 
afirmando además desconocer los porqués de su realización. Sin embargo, con frecuencia los atestiguan y acompañan, lo que constituye en sí una forma pedagógica de aprendizaje vivencial. Probablemente, llegado su momento serán quienes encabecen su organización.

La transmisión oral de la herencia espiritual y cultural es la que conduce a los tojolabales a participar en la rememoración constante de sus prácticas culturales. Éstas son las que revitalizan contenidos procedentes de la apropiación como memoria adquirida. Si entendemos que, como valor social y cultural, la memoria "es reivindicación de un pasado que se quiere impedir que pase al olvido" (Aróstegui, 2004: 27), entonces dicha participación tojolabal en las romerías y fiestas patronales es memoria de un pasado que también tiene función reivindicativa, de frente a una posible negación, ocultamiento o invisibilización galopantes en los tiempos actuales.

Por todo lo antes expuesto, así como por las experiencias vividas y lo que hemos escuchado de parte de los tojolabales participantes en las fiestas patronales y las romerías, corroboramos lo expresado también por Lenkersdorf (1996: 164) en cuanto a que: "Las fiestas tienen un lugar especial en la caracterización de la cultura y el arte de los tojolabales" y que dichas fiestas patronales y las romerías hoy forman parte de una memoria colectiva que es tanto de los indígenas mayas tojolabales como de los pobladores de los lugares a los que acuden, así como también de la gente mestiza de Comitán.

En este sentido y en concordancia con Fábregas (2012: 68): "Estas peregrinaciones son esenciales no sólo para entender los nexos históricos de los tojolabales, sino para comprender también su configuración como un pueblo con identidad propia”. Este pueblo, como hemos confirmado, ha creado una variedad de símbolos y significados con un sentido muy propio, que sus integrantes y personas partícipes de otros grupos culturales han llegado a objetivar y aceptar. Así lo figura San Martín (1999: 180) cuando dice que: "El sentido inventado, creado o instituido por un individuo, debe sedimentarse, adquirir consistencia objetiva, adquirir cuerpo". Esto es que el sentido inventado debe configurarse frente al acto de creación para que pueda seguir siendo recuperado por sus creadores, dígase en este caso: los indígenas mayas tojolabales.

Atestiguamos que la participación indígena tojolabal en estas fiestas comunitarias, romerías, viajes largos o peregrinaciones son una confirmación de su identidad y una relación constante con sus antepasados mayas. Es una insistencia constante por la renovación de lo ancestral y de la importancia vital de la agricultura, esto es, de una relación de dependencia de los ritmos, fenómenos y tiempos de la naturaleza.

Lo anterior confirma la máxima de que: "la naturaleza es parte intrínseca de la necesidad humana, ésta se convierte en el monumento imaginario que producirá la representación inmanente de la sociedad" (Pérez-Taylor, 2002: 38). Y los tojolabales encontraron en sus prácticas tradicionales esa colaboración entre el hombre y la naturaleza, donde se verifica la transmisión e influencia de los saberes ancestrales mayas que les están permitiendo construir sus conocimientos culturales, como forma de hacer frente a las condiciones cambiantes de la vida social, de las relaciones económicas y de la relación con la naturaleza.

Con su involucramiento en todos estos eventos de una manera muy protagónica, la gente participante de este pueblo maya está dejando una impronta sociocultural que trasciende a su propio pueblo, contribuyendo a una memoria y a una identidad más amplias, con alcance, en este caso, a la gente de la ciudad de Comitán. De igual forma contribuyen sustantivamente a la recreación del aspecto sagrado que interacciona con el de la diversión, como elementos característicos de las fiestas religiosas. Así mismo con todos estos recorridos que se afirman como trazos y articulaciones dentro de un espacio vivido, se logra una configuración territorial más amplia que no sólo aquella que da cabida a las localidades habitadas. 
La constelación plena que significa la realización de todas estas romerías y la participación en las fiestas patronales, ponen de manifiesto el deseo de una construcción constante del sentido comunal, de sacralidad, de relación con la naturaleza y de la memoria como elementos clave en el modo de vida de los tojolabales, es decir: de la manera como configuran su visión y comprensión cultural del mundo y de la vida.

Convendrá dar seguimiento a la participación creciente de la gente tojolabal en las fiestas patronales para poder lograr una comprensión histórica y cultural más apegada a los dinamismos que las caracterizan y para poder aquilatar la presencia de este pueblo maya en un espacio urbano en el que fueron despreciados durante décadas. Así mismo se podrá analizar la participación indígena en el campo religioso en debate entre diversos credos.

\section{Referencias}

Adorno, Theodore. 1990. Dialéctica negativa. Madrid, España: Editorial Taurus Humanidades. Aróstegui, Julio. 2004. Memoria, memoria histórica e historiografía. Precisión conceptual y uso por el historiador. Pasado y memoria. Revista de historia contemporánea, 3(3): 15-36. http://dx.doi.org/10.14198/ PASADO2004.3.02

Argüello, Carmen. 1981. Recopilación cronológica de datos sobre Comitán de Domínguez. Comitán de Domínguez, Chiapas, México.

Basauri, Carlos. 1931. Tojolabales, tzeltales y mayas. Breves apuntes sobre antropología, etnografía y lingüística. México: Talleres Gráficos de la Nación.

Becerra, Marcos. 1932. Nombres geográficos e indígenas del estado de Chiapas. Tuxtla Gutiérrez, Chiapas, México: Talleres tipográficos del Gobierno del Estado.

Briones, Rafael. 1991. Identidad y poder en las fiestas patronales de Los Guájares. Gazeta de Antropología, 8(8): 1-13

Fábregas, Andrés. 2012. El mosaico chiapaneco. Etnografía de las culturas indígenas. México, D.F.: Comisión Nacional para el Desarrollo de los Pueblos Indígenas (CDI), Delegación Chiapas.

Fernández, Francisco. 1995. Celebrar a los santos. Sistema de fiestas en el noroccidente de Yucatán. Revista Alteridades, 5(9): 51-61.

Gómez, Antonio y Mario Ruz. 1992. Memoria baldía. Los tojolabales y las fincas. Testimonios. México, D.F.: Fuentes Impresores, S. A., Instituto de Investigaciones Filológicas, Centro de Estudios Indígenas, UNACH. Grimson, Alejandro. 1997. Relatos de la diferencia y la igualdad. Los bolivianos en Buenos Aires. Revista Nueva Sociedad, Comunicación, Culturas e Identidades en el Fin de Siglo, 26(147): 96-107.

Harvey, David. 2008. La condición de la posmodernidad: investigación sobre los orígenes del cambio cultural. Buenos Aires-Madrid: Amorrortu editores.

INEGI -Instituto Nacional de Estadística y Geografía-. 2010. Censo de población y vivienda. http://www3. inegi.org.mx/sistemas/iter/default.aspx?ev=5 (07 de marzo, 2017).

Inestrosa, Sergio. 1994. Vivir la fiesta, un desenfreno multimediado. México: Universidad Iberoamericana. Biblioteca Francisco Xavier Clavijero. Centro de Información Académica.

Lenkersdorf, Carlos. 1979. b'omak'umal tojol ab'al - kastiya. Diccionario tojolabal - español. Idioma mayence de los Altos de Chiapas. Volumen Uno. México 20, D.F.: Editorial Nuestro Tiempo. 
Lenkersdorf, Carlos. 1996. Los hombres verdaderos. Voces y testimonios tojolabales. Lengua y sociedad, naturaleza y cultura, artes y comunidad cósmica. México, D. F.: Editorial XXI.

Lenkersdorf, Gudrum. 1986. Contribuciones a la historia colonial de los tojolabales. En Los Legítimos Hombres, Aproximación antropológica al grupo tojolabal. Volumen $I V$, editado por Mario Humberto Ruz. México, D. F.: Centro de Estudios Mayas, Instituto de Investigaciones Filológicas, Universidad Nacional Autónoma de México, 13-102.

Limón, Fernando 2010. Conocimiento cultural y existencia entre los chuj. México: Comisión Nacional para el Desarrollo de los Pueblos Indígenas (CDI).

Nájera, Antonio. 2009. Prácticas alimentarias en comunidades del pueblo tojolabal. Tesis presentada como requisito parcial para optar al grado de Maestría en Ciencias en Recursos Naturales y Desarrollo Rural, San Cristóbal de las Casas, Chiapas. México: El Colegio de la Frontera Sur (ECOSUR).

Nora, Pierre. 1997. Entre la memoria y la historia (Les Lieux de Mémoire). Paris, Gallimard.

Pérez-Taylor, Rafael. 2002. Entre la tradición y la modernidad: Antropología de la memoria colectiva. México, D.F.: Universidad Nacional Autónoma de México, Instituto de Investigaciones Antropológicas, Plaza y Valdés S.A. de C.V.

Pérez, Carlos y Lourdes Vargas. 2009. La memoria colectiva en las comunidades indígenas, una estrategia para la construcción de identidad. Revista del Pensamiento Sociológico Veredas, 10(número especial): 85102.

Pulido, María. 2006. Comitán en la historia. Breve historia documentada de Comitán de Domínguez, Chiapas. 450 años de identidad comiteca 1556-2006. México: Editorial Entre Tejas.

Pulido, María.2010. Comitán en el umbral de la historia. Comitán de Domínguez: Archivo Histórico Municipal de Comitán.

Quijano, Aníbal. 1993. Colonialidad del poder, eurocentrismo y América Latina. CLACSO http://bibliotecavirtual.clacso.org.ar/clacso/sur-sur/20100708034410/lander.pdf (18 de marzo, 2017).

Rodas, Jaime. 1968. Recopilación de datos históricos y tradicionales de la ciudad de Comitán de Domínguez, Chiapas, México. Comitán de Domínguez: Archivo Histórico Municipal de Comitán de Domínguez.

Román, Leticia. 2005. Comitán: Un lugar para soñar. Calendario gastronómico. Ferias, tradiciones, costumbres y remembranzas. México: Ediciones Gernika, S. A.

Ruz, Mario. 1981. Los legítimos hombres, aproximación antropológica al grupo tojolabal. Volumen 1. México, D. F.: Centro de Estudios Mayas, Instituto de Investigaciones Filológicas, Universidad Nacional Autónoma de México.

Ruz, Mario. 1982. Los legítimos hombres, aproximación antropológica al grupo tojolabal. Volumen 2. México, D. F.: Centro de Estudios Mayas, Instituto de Investigaciones Filológicas, Universidad Nacional Autónoma de México.

San Martín, Javier. 1999. Teoría de la cultura. Madrid: Editorial Síntesis.

Sztulwark, Pablo. 2006. Ciudad memoria, monumento, lugar y situación urbana. Summa+, 14(81): 94-97. Walsh, Catherine y Juan García. 2010. Derechos, territorio ancestral y el pueblo afroesmeraldeño. ¿Estado constitucional de derechos?: informe sobre derechos humanos Ecuador 2009, compilado por Universidad Andina Simón Bolívar. Sede Ecuador. Programa Andino de Derechos Humanos, PADH. Quito: Universidad Andina Simón Bolívar. Sede Ecuador. 